\title{
Pengaruh Earning Per Share dan Return On Asset terhadap Harga Saham pada PT. Sepatu Bata Indonesia Tbk.
}

\author{
${ }^{1}$ Cristine Prestarika Lukito*, ${ }^{2}$ Priski Setiawan \\ ${ }^{1,2}$, Universitas Pamulang
}

\author{
Alamat Surat \\ Email: 1dosen02603@unpam.ac.id*,2 priski@ stabdharmawidya.ac.id
}

Article History:

Received: 10-Nopember-2020; Received in Revised: 25-Nopember-2020; Accepted: 30-Nopember-2020

\begin{abstract}
ABSTRAK
Penelitian ini bertujuan untuk mengetahui Pengaruh Earning per share dan Return on Asset Terhadap Harga saham pada PT. Sepatu Bata Indonesia Tbk. Metode yang digunakan adalah explanatory research. Teknik analisis menggunakan analisis statistik dengan pengujian regresi, korelasi, determinasi dan uji hipotesis. Hasil penelitian ini Earning per share tidak berpengaruh signifikan terhadap Harga saham sebesar 3,5\%, uji hipotesis diperoleh $t$ hitung < t tabel atau $(-0,134<2,447)$. Return on Asset berpengaruh signifikan terhadap Harga saham sebesar 58,0\%, uji hipotesis diperoleh $\mathrm{t}$ hitung $>\mathrm{t}$ tabel atau $(2,876>2,447)$. Earning per share dan Return on Asset secara simultan berpengaruh signifikan terhadap Harga saham diperoleh persamaan regresi $\mathrm{Y}=442,106+-7,197 \mathrm{X} 1$ $+51,683 \mathrm{X} 2$ dan nilai determinasi sebesar $83,2 \%$, uji hipotesis diperoleh nilai $\mathrm{F}$ hitung $>\mathrm{F}$ tabel atau $(12,367>5,410)$.
\end{abstract}

\section{Kata kunci: Earning Per Share, Return on Asset, Harga Saham}

\section{ABSTRACT}

This study aims to determine the effect of earning per share and return on assets on PT's stock prices. Sepatu Bata Indonesia Tbk. The method used is explanatory research. The analysis technique uses statistical analysis with regression testing, correlation, determination, and hypothesis testing. This study's results Earning per share have no significant effect on stock prices by 3.5\%; hypothesis testing obtained t count $<t$ table or $(-0.134<2.447)$. Return on Asset has a significant effect on stock prices by 58.0\%; hypothesis testing obtained $t$ count $>t$ table or (2.876> 2.447). Earning per share and Return on Assets simultaneously have a significant effect on stock prices, the regression equation is $Y=442,106+-7,197 X 1+51,683 X 2$ and a determination value of $83.2 \%$, hypothesis testing obtained $F$ value $>F$ table or $(12,367>5,410)$.

Keywords: Earning Per Share, Return on Asset, Stock Price

\section{PENDAHULUAN}

Kinerja keuangan suatu perusahaan dapat diartikan sebagai prospek atau masa depan pertumbuhan potensi perkembangan yang baik bagi perusahaan, investasi di pasar modal merupakan salah satu cara yang dapat ditempuh oleh perusahaan dalam meningkatkan laba. Informasi kinerja keuangan diperlukan untuk menilai perusahaan potensial sumber daya ekonomi. Laporan keuangan merupakan sebuah media informasi yang mencatat merangkum segala aktivitas perusahaan dan dibutuhkan untuk melaporkan keadaan dan posisi keuangan perusahaan terhadap pihak yang berkepentingan terutama pada pihak kreditur, visitor dan manajemen perusahaan itu sendiri. Informasi yang terkandung di dalam suatu laporan keuangan diperlukan suatu analisis laporan 
keuangan jika informasi disajikan dengan benar informasi tersebut berguna bagi perusahaan dalam pengambilan keputusan dan untuk mengetahui kinerja perusahaan.

Dalam analisis laporan keuangan dapat dilakukan menggunakan rasio keuangan. Rasio-rasio yang digunakan untuk menilai kinerja keuangan perusahaan seperti ratio likuiditas, ratio leverage, ratio aktivitas dan ratio profitabilitas. Analisis ratio memungkinkan untuk mengevaluasi kondisi keuangan dan pihak berkepentingan menunjukkan kondisi sehat tidaknya suatu perusahaan. Selain itu kinerja laporan keungan merupakan salah satu factor untuk mengambil keputusan untuk berinfestasi. Jenis rasio yang di gunakan dalam penelitian ini adalah Ratio Profitabilitas yang terdiri dari Return On Asset dan Earning Per Share.

Profitabilitas mempunyai arti penting dalam usaha mempertahankan kelangsungan hidupnya dalam jangka panjang, karena profitabilitas menunjukan apakah badan usaha tersebut mempunyai prospek yang baik di masa yang akan datang. Dengan demikian setiap badan usaha akan selalu berusaha meningkatkan profitabilitasnya, karena semakin tinggi tingkat profitabilitas suatu badan usaha makan kelangsungan hidup badan usaha tersebut akan lebih terjamin.

Ratio Profitabilitas digunakan untuk mengukur seberapa efektif perusahaan memanfaatkan sumber ekonomi yang ada untuk menciptakan laba. Return On Asset merupakan rasio yang menunjukan hasil (Pengembalian) atas jumlah aktifa yang di gunakan dalam perusahaan, semakin kecil (rendah) rasio ini, semakin kurang baik, demikian pula sebaliknya.

Earning Per Share (EPS) merupakan perbandingan antara earning (dalam hal ini laba bersih setelah pajak) dengan jumlah lembar saham perusahan. Bagi para infestor, informasi EPS merupakan informasi yang dianggap paling mendasar dan berguna, karena bisa menggambarkan prospek earning di perusaan masa depan. Profitabilitas keuangan perusahaan sudah tentu merupakan kinerja perusahaan yang ditinjau dari kondisi keuangan perusahaan profitabilitas keuangan perusahaan tercermin dari kondisi keuangannya Oleh sebab itu untuk mengukur profitabilitas keuangan perusahaan diperlukan Analisis terhadap laporan keuangannya.

Harga saham merupakan harga yang terbentuk di bursa saham secara umumnya harga saham diperoleh untuk menghitung nilai saham nya semakin jauh perbedaan tersebut maka hal ini mencerminkan terlalu sedikitnya informasi yang mengalir ke Bursa Efek, maka harga saham tersebut cenderung dipengaruhi oleh tekanan psikologis pembeli atau penjual untuk mencegah hal tersebut sebaiknya perusahaan setiap saat memberi informasi yang cukup ke Bursa Efek sepanjang informasi tersebut berpengaruh terhadap harga pasar saham nya upaya untuk memasukkan Bagaimana menghitung harga saham yang Sesungguhnya telah dilakukan oleh setiap analisis dengan tujuan untuk dapat memperoleh tingkat keuntungan yang memuaskan.

Harga saham merupakan harga yang terbentuk di bursa saham secara umumnya harga saham diperoleh untuk menghitung nilai saham nya, semakin jauh perbedaan tersebut maka hal ini mencerminkan terlalu sedikitnya informasi yang mengalir ke Bursa Efek maka harga saham tersebut cenderung dipengaruhi oleh tekanan psikologis pembeli atau penjual untuk mencegah hal tersebut sebaiknya perusahaan setiap saat memberi informasi yang cukup ke Bursa Efek sepanjang informasi tersebut berpengaruh terhadap harga pasar saham nya upaya untuk memasukkan.

PT. Sepatu Bata Indonesia Tbk merupakan perusahaan industri manufaktur yang menghasilkan produk sepatu dan sandal baik sepatu resmi dan santai untuk pria maupun wanita. PT. Sepatu Bata Indonesia Tbk ini melakukan proses produksi secara terus menerus dan dituntut untuk menghasilkan produk yang baik dengan tepat waktu karena produk sepatu yang dihasilkan ini merupakan salah satu produk yang paling diminati konsumen di Indonesia dari kalangan menengah ke bawah sampai kalangan menengah ke atas.

Komposisi aktiva dan laba pada neraca merupakan cerminan dari keberhasilan suatu perusahaan. Sebagian besar kegiatan keuangan berhubungan dengan harga saham suatu pekerjaan yang tampak sederhana tetapi apabila di kelola dengan sungguh-sungguh berpeluang berburu tingkat profitabilitas yang akhiran memungkinkan perusahaan mengalami kebangkrutan. Kondisi ekonomi yang berfluktuasi mengakibatkan tidak stabilnya kinerja perusahaan sektor industri dapat dilihat pada tabel berikut: 
Tabel Earning Per Share, Return on Asset dan Harga Saham

PT. Sepatu Bata Indonesia Tbk. Periode 2012-2019

\begin{tabular}{|c|c|c|c|}
\hline Tahun & Earning Per Share & Return on Asset & Harga Saham \\
\hline 2012 & 43.55 & 10.95 & 550 \\
\hline 2013 & 53.34 & 12.07 & 600 \\
\hline 2014 & 34.13 & 16.51 & 1060 \\
\hline 2015 & 54.84 & 19.19 & 1105 \\
\hline 2016 & 99.15 & 16.28 & 610 \\
\hline 2017 & 32.49 & 5.24 & 690 \\
\hline 2018 & 41.27 & 6.27 & 412 \\
\hline 2019 & 40.55 & 5.96 & 415 \\
\hline
\end{tabular}

Pada tabel di atas dapat di lihat bahwa sepanjang tahun 2012-2019 PT. Sepatu Bata Indonesia Tbk mengalami perkembangan yang fluktuatif. Akibat tidak stabilnya kinerja keuangan. Dari data di atas, terlihat bahwa perusahaan mengalami penurunan ROA dan EPS di tahun 2013 tetapi harga saham tidak ikut turun, dan pada tahun 2015 EPS dan ROA mengalami kenaikan akan tetapi tidak di sertai kenaikan harga saham yang mengalami penurunan. Oleh karena itu perlu di adakannya penelitian lebih lanjut untuk mengetahui pengaruh harga saham terhadap investor yang melakukan investasi pada perusahaan PT. Sepatu Bata Indonesia Tbk.

\subsection{Kajian Pustaka \\ Earning Per Share}

Menurut Kasmir (2015:115) rasio laba per saham (Earning Per Share) atau disebut juga rasio nilai buku, merupakan rasio untuk mengukur keberhasilan manajemen dalam mencapai keuntungan bagi pemegang saham. Rasio yang rendah berarti manajemen belum berhasil untuk memuaskan pemegang saham, sebaliknya dengan rasio yang tingi, maka kesejahteraan pemegang saham meningkat dengan pengertian lain bahwa tingkat pengembalian yang tinggi.

\section{Return on Asset}

Menurut Kasmir (2014:201) Return on Asset merupakan rasio yang menunjukkan hasil (return) atas jumlah aktiva yang digunakan dalam perusahaan. Selain itu, Return on Asset memberikan ukuran yang lebih baik atas profitabilitas perusahaan karena menunjukkan efektivitas manajemen dalam menggunakan aktiva untuk memperoleh pendapatan.

\section{Harga Saham}

Merupakan harga suatu saham pada pasar yang sedang berlangsung di bursa efek. Harga pasar mewakili harga perusahaan penerbitnya. Menurut Harsono (2013:19) saham didefinisikan sebagai bukti atau sertifikat kepemilikan seseorang atau suatu badan terhadap perusahaan yang menerbitkan sekruitas tersebut, yang dapat pula diartikan sebagai keikutsertaan investor sebagai pemodal pada suatu perusahaan sehingga memiliki hak klaim atas penghasilan dan aktiva perusahaan tersebut.

\section{METODE}

Jenis penelitian yang dipakai adalah asosiatif, dimana tujuannya adalah untuk mengetahui mencari keterhubungan antar variabel independen terhadap variabel dependen. Populasi dalam penelitian ini berdasar laporan keuangan selama 8 tahun PT. Sepatu Bata Indonesia Tbk. Teknik pengambilan sampling dalam penelitian ini adalah sampel jenuh, dimana semua anggota populasi dijadikan sebagai sampel. Dengan demikian sampel dalam penelitian ini laporan keuangan selama 8 tahun. Dalam menganalisis data digunakan uji asumsi klasik, regresi, koefisien korelasi, koefisien determinasi dan uji hipotesis baik parsial maupun simultan. 


\section{HASIL DAN PEMBAHASAN}

\subsection{Hasil}

\section{Analisis Deskriptif}

Pada pengujian ini digunakan untuk mengetahui besarnya persentase minimum dan maksimum, persentase rata-rata dan standar deviasi dari masing-masing variabel. Adapun hasilnya sebagai berikut:

Tabel Hasil Analisis Descriptive Statistics

\begin{tabular}{|c|c|c|c|c|c|}
\hline \multicolumn{6}{|c|}{ Descriptive Statistics } \\
\hline & $\mathrm{N}$ & Minimum & Maximum & Mean & Std. Deviation \\
\hline EPS (X1) & 8 & 32.49 & 99.15 & 49.9150 & 21.43369 \\
\hline ROA (X2) & 8 & 5.24 & 19.19 & 11.5588 & 5.41053 \\
\hline Harga Saham (Y) & 8 & 412 & 1105 & 680.25 & 266.022 \\
\hline Valid N (listwise) & 8 & & & & \\
\hline
\end{tabular}

Earning per share diperoleh nilai minimum sebesar 32,49\% dan nilai maximum $99,15 \%$ dengan rata-rata sebesar 49,91\% dengan standar deviasi 21,43\%.

Return on Asset diperoleh nilai minimum sebesar 5,24\% dan nilai maximum 19,19\% dengan nilai rata-rata sebesar $11,55 \%$ dengan standar deviasi $5,41 \%$.

Harga saham diperoleh nilai minimum sebesar 412 dan nilai maximum 1.105 dengan rata-rata sebesar 680 dengan standar deviasi 266,02

\section{Analisis Verifikatif.}

Pada analisis ini dimaksudkan untuk mengetahui pengaruh variabel independen terhadap variabel dependen. Adapun hasil pengujian sebagai berikut:

\section{Analisis Regresi Linier Berganda}

Uji regresi ini dimaksudkan untuk mengetahui perubahan variabel dependen jika variabel independen mengalami perubahan. Adapun hasil pengujiannya sebagai berikut:

Tabel Hasil Pengujian Regresi Liner Berganda

\begin{tabular}{|c|c|c|c|c|c|}
\hline \multirow[b]{3}{*}{ Model } & \multicolumn{2}{|c|}{ Coefficients $^{\mathbf{a}}$} & \multirow[b]{2}{*}{$\begin{array}{l}\text { Standardized } \\
\text { Coefficients }\end{array}$} & \multirow[b]{3}{*}{$\mathrm{t}$} & \multirow[b]{3}{*}{ Sig. } \\
\hline & \multicolumn{2}{|c|}{$\begin{array}{l}\text { Unstandardized } \\
\text { Coefficients }\end{array}$} & & & \\
\hline & $\mathrm{B}$ & Std. Error & Beta & & \\
\hline $\begin{array}{ll}1 & (\text { Constant })\end{array}$ & 442.106 & 134.124 & & 3.296 & .022 \\
\hline EPS (X1) & -7.197 & 2.628 & -.580 & -2.739 & .041 \\
\hline ROA (X2) & 51.683 & 10.410 & 1.051 & 4.965 & .004 \\
\hline
\end{tabular}

a. Dependent Variable: Harga saham (Y)

Berdasarkan hasil pengujian pada tabel di atas, diperoleh persamaan regresi $\mathrm{Y}=442,106$ 7,197X1 + 51,683X2. Dari persamaan tersebut dijelaskan sebagai berikut:

a. Konstanta sebesar 442,106 diartikan jika Earning per share dan Return on Asset tidak ada, maka telah terdapat nilai Harga saham sebesar 442,106 point.

b. Koefisien regresi Earning per share sebesar -7,197, angka ini positif artinya setiap ada peningkatan Earning per share sebesar -7,197 maka Harga saham juga akan mengalami peningkatan sebesar -7,197 point. 
c. Koefisien regresi Return on Asset sebesar 51,683, angka ini positif artinya setiap ada peningkatan Return on Asset sebesar 51,683 maka Harga saham juga akan mengalami peningkatan sebesar 51,683 point.

\section{Analisis Koefisien Korelasi}

Analisis koefisien korelasi dimaksudkan untuk mengetahui tingkt kekuatan hubungan dari variabel independen terhadap variabel dependen baik secara parsial maupun simultan. Adapun hasil pengujian sebagai berikut:

Tabel Hasil Pengujian Koefisien Korelasi Earning per share Terhadap Harga saham.

\section{Correlations $^{b}$}

\begin{tabular}{ll|r|r} 
& & Earning per share & \\
& & (X1) & Harga saham (Y) \\
\hline EPS (X1) & Pearson Correlation & 1 & -.054 \\
\cline { 2 - 4 } & Sig. (2-tailed) & & .898 \\
\hline Harga Saham (Y) & Pearson Correlation & -.054 & 1 \\
\cline { 2 - 4 } & Sig. (2-tailed) & .898 & \\
\hline
\end{tabular}

Berdasarkan hasil pengujian diperoleh nilai korelasi sebesar - 0,054 artinya Earning per share memiliki hubungan yang sangat lemah terhadap Harga saham.

Tabel Hasil Pengujian Koefisien Korelasi Return on Asset Terhadap Harga saham.

\section{Correlations $^{\mathrm{b}}$}

\begin{tabular}{llr|r} 
& & Return on Asset \\
& & $(\mathrm{X} 2)$ & \multicolumn{1}{c}{ Harga saham (Y) } \\
\hline ROA (X2) & Pearson Correlation & 1 & $.761^{*}$ \\
\cline { 2 - 4 } & Sig. (2-tailed) & & .028 \\
\hline Harga Saham (Y) & Pearson Correlation & $.761^{*}$ & 1 \\
\cline { 2 - 4 } & Sig. (2-tailed) & .028 & \\
\hline
\end{tabular}

Berdasarkan hasil pengujian diperoleh nilai korelasi sebesar 0,761 artinya Return on Asset memiliki hubungan yang kuat terhadap Harga saham.

Tabel Hasil Pengujian Koefisien Korelasi Earning per share dan Return on Asset secara simultan Terhadap Harga saham.

\section{Model Summary}

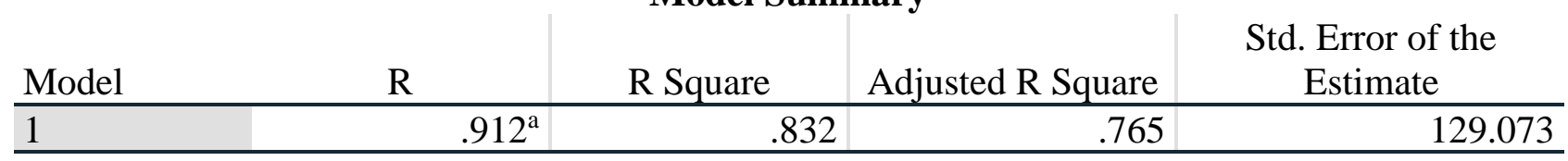

a. Predictors: (Constant), ROA (X2), EPS (X1)

Berdasarkan hasil pengujian diperoleh nilai korelasi sebesar 0,912 artinya Earning per share dan Return on Asset secara simultan memiliki hubungan yang sangat kuat terhadap Harga saham.

\section{Analisis Koefisien Determinasi}


Analisis koefisien determinasi dimaksudkan untuk mengetahui besarnya persentase pengaruh dari variabel independen terhadap variabel dependen baik secara parsial maupun simultan. Adapun hasil pengujian sebagai berikut:

Tabel Hasil Pengujian Koefisien Determinasi Earning per share Terhadap Harga saham.

\begin{tabular}{|c|c|c|c|c|}
\hline \multicolumn{5}{|c|}{ Model Summary } \\
\hline Model & $\mathrm{R}$ & R Square & Adjusted R Square & $\begin{array}{l}\text { Std. Error of the } \\
\text { Estimate }\end{array}$ \\
\hline 1 & $.054^{\mathrm{a}}$ & .003 & -.163 & 286.910 \\
\hline
\end{tabular}

a. Predictors: (Constant), EPS (X1)

Berdasarkan hasil pengujian diperoleh nilai determinasi sebesar 0,003 artinya Earning per share memiliki kontribusi pengaruh sebesar 3,5\% terhadap Harga saham.

Tabel Hasil Pengujian Koefisien Determinasi Return on Asset Terhadap Harga saham.

\begin{tabular}{|c|c|c|c|c|}
\hline \multicolumn{5}{|c|}{ Model Summary } \\
\hline Model & $\mathrm{R}$ & R Square & Adjusted R Square & $\begin{array}{l}\text { Std. Error of the } \\
\text { Estimate }\end{array}$ \\
\hline 1 & $.761^{\mathrm{a}}$ & .580 & .510 & 186.305 \\
\hline
\end{tabular}

a. Predictors: (Constant), ROA (X2)

Berdasarkan hasil pengujian diperoleh nilai determinasi sebesar 0,580 artinya Return on Asset memiliki kontribusi pengaruh sebesar 58,0\% terhadap Harga saham.

Tabel 8. Hasil Pengujian Koefisien Determinasi Earning per share dan Return on Asset Terhadap Harga saham.

Model Summary

\begin{tabular}{lrr|rr|r} 
Model & & R & \multicolumn{2}{c}{$\begin{array}{c}\text { Std. Error of the } \\
\text { Estimate }\end{array}$} \\
\hline 1 & R Square & Adjusted R Square & .765 & 129.073 \\
\hline
\end{tabular}

a. Predictors: (Constant), ROA (X2), EPS (X1)

Berdasarkan hasil pengujian diperoleh nilai determinasi sebesar 0,832 artinya Earning per share dan Return on Asset secara simultan memiliki kontribusi pengaruh sebesar 83,2\% terhadap Harga saham, sedangkan sisanya sebesar $16,8 \%$ dipengaruhi faktor lain.

\section{Uji Hipotesis}

\section{Uji hipotesis Parsial (Uji t)} diterima.

Pengujian hipotesis dengan uji t digunakan untuk mengetahui hipotesis parsial mana yang

Tabel Hasil Uji Hipotesis Earning per share Terhadap Harga saham.

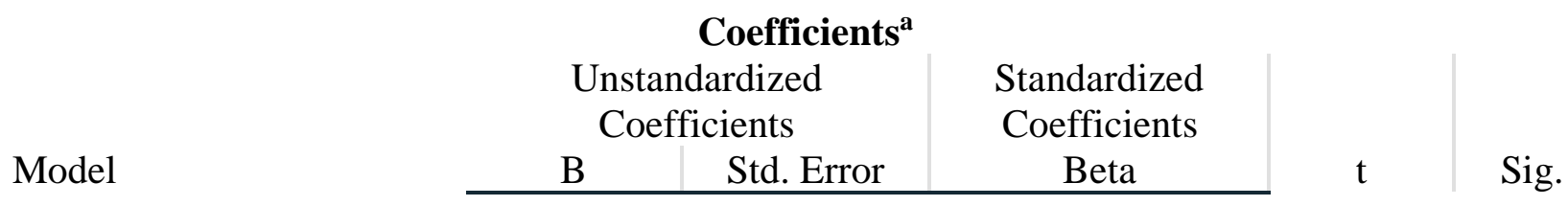




\begin{tabular}{r|r|r|r|r|r|r}
\hline 1 & (Constant) & 713.992 & 272.151 & & 2.624 & .039 \\
\cline { 2 - 7 } & EPS $(\mathrm{X} 1)$ & -.676 & 5.059 & -.054 & -.134 & .898 \\
\hline
\end{tabular}

a. Dependent Variable: Harga saham (Y)

Berdasarkan hasil pengujian pada tabel di atas, diperoleh nilai t hitung $<\mathrm{t}$ tabel atau $(-0,134<2,447)$, dengan demikian tidak terdapat pengaruh yang signifikan atara Earning per share terhadap Harga saham.

Tabel Hasil Uji Hipotesis Return on Asset Terhadap Harga saham.

\begin{tabular}{|c|c|c|c|c|c|c|}
\hline \multicolumn{7}{|c|}{ Coefficients $^{\mathrm{a}}$} \\
\hline & & \multicolumn{2}{|c|}{ Unstandardized Coefficients } & $\begin{array}{c}\text { Standardized } \\
\text { Coefficients }\end{array}$ & & \\
\hline \multicolumn{2}{|c|}{ Model } & $\mathrm{B}$ & Std. Error & Beta & $\mathrm{t}$ & Sig. \\
\hline \multirow[t]{2}{*}{1} & (Constant) & 247.586 & 164.223 & & 1.508 & .182 \\
\hline & ROA (X2) & 37.432 & 13.015 & .761 & 2.876 & .028 \\
\hline
\end{tabular}

a. Dependent Variable: Harga saham (Y)

Berdasarkan hasil pengujian pada tabel di atas, diperoleh nilai t hitung $>\mathrm{t}$ tabel atau $(2,876>2,447)$, dengan demikian terdapat pengaruh yang signifikan atara Return on Asset terhadap Harga saham.

\section{Uji Hipotesis Simultan (Uji F)}

Pengujian hipotesis dengan uji $\mathrm{F}$ digunakan untuk mengetahui hipotesis simultan yang mana yang diterima.

Tabel Hasil Uji Hipotesis Earning per share dan Return on Asset Terhadap Harga saham.

\begin{tabular}{|c|c|c|c|c|c|c|}
\hline \multicolumn{7}{|c|}{ ANOVA $^{\mathrm{a}}$} \\
\hline & & Sum of Squares & df & Mean Square & $\mathrm{F}$ & Sig. \\
\hline \multirow[t]{3}{*}{1} & Regression & 412074.655 & 2 & 206037.327 & 12.367 & $.012^{\mathrm{b}}$ \\
\hline & Residual & 83298.845 & 5 & 16659.769 & & \\
\hline & Total & 495373.500 & 7 & & & \\
\hline
\end{tabular}

Berdasarkan hasil pengujian pada tabel di atas, diperoleh nilai $\mathrm{F}$ hitung $>\mathrm{F}$ tabel atau $(12,367>$ $5,410)$, dengan demikian terdapat pengaruh yang signifikan atara Earning per share dan Return on Asset terhadap Harga saham.

\subsection{Pembahasan}

\section{Pengaruh Earning per share Terhadap Harga saham}

Earning per share berpengaruh signifikan terhadap Harga saham dengan korelasi sebesar 0,054 atau memiliki hubungan yang sangat lemah dengan kontribusi pengaruh sebesar 3,5\%. Pengujian hipotesis diperoleh nilai $t$ hitung $<\mathrm{t}$ tabel atau $(-0,134<2,447)$. Dengan demikian tidak terdapat pengaruh signifikan antara Earning per share terhadap Harga saham.

\section{Pengaruh Return on Asset Terhadap Harga saham}

Return on Asset berpengaruh signifikan terhadap Harga saham dengan korelasi sebesar 0,761 atau memiliki hubungan yang kuat dengan kontribusi pengaruh sebesar 58,0\%. Pengujian hipotesis diperoleh nilai t hitung $>\mathrm{t}$ tabel atau $(2,876>2,447)$. Dengan demikian terdapat pengaruh signifikan antara Return on Asset terhadap Harga saham. 


\section{Pengaruh Earning per share dan Return on Asset Terhadap Harga saham}

Earning per share dan Return on Asset berpengaruh signifikan terhadap Harga saham dengan diperoleh persamaan regresi $\mathrm{Y}=442,106+-7,197 \mathrm{X} 1+51,683 \mathrm{X} 2$, nilai korelasi sebesar 0,912 atau memiliki hubungan yang sangat kuat dengan kontribusi pengaruh sebesar $83,2 \%$ sedangkan sisanya sebesar $16,8 \%$ dipengaruhi faktor lain. Pengujian hipotesis diperoleh nilai $\mathrm{F}$ hitung $>\mathrm{F}$ tabel atau $(12,367>5,410)$. Dengan demikian terdapat pengaruh signifikan antara Earning per share dan Return on Asset terhadap Harga saham.

\section{KESIMPULAN}

\subsection{Kesimpulan}

a. Earning per share tidak berpengaruh signifikan terhadap Harga saham dengan kontribusi pengaruh sebesar 3,5\%. Uji hipotesis diperoleh nilai t hitung $<\mathrm{t}$ tabel atau $(-0,134<2,447)$.

b. Return on Asset berpengaruh signifikan terhadap Harga saham dengan kontribusi pengaruh sebesar 58,0\%. Uji hipotesis diperoleh nilai t hitung $>\mathrm{t}$ tabel atau $(2,876>2,447)$.

c. Earning per share dan Return on Asset berpengaruh signifikan terhadap Harga saham dengan kontribusi pengaruh sebesar $83,2 \%$ sedangkan sisanya sebesar $16,8 \%$ dipengaruhi faktor lain. Uji hipotesis diperoleh nilai F hitung > F tabel atau $(12,367>5,410)$.

\subsection{Saran}

a. Perusahaan harus selalu menjaga nilai buku dengan mengukur keuntungan agar nilai EPS tetap terjaga

b. Perusahaan harus menjaga nilai ROA tetap terjaga dengan mengefisiensi biaya operasional yang dapat diminimalisir

c. Kinerja perusahaan dapat ditingkatkan dengan selalu mengaudit financial secara kontinyu sehingga diketahui performace perubahan dapat diproyeksi lebih awal.

\section{DAFTAR PUSTAKA}

Agus Sartono. (2010). "Manajemen Keuangan Toeri dan Aplikasi”, Edisi keempat, Yogyakarta: Penerbit BPFE.

Algifari. (2015). “Analisis Regresi untuk Bisnis dan Ekonomi”. Yogyakarta: BPFE.

Amelia, R. W., \& Sunarsi, D. (2020). Pengaruh Return On Asset Dan Return On Equity Terhadap Debt To Equity Ratio PadA PT. Kalbe Farma, TBK. Ad Deenar: Jurnal Ekonomi dan Bisnis Islam, 4(01), 105-114.

Arikunto, Suharsimi (2014). “Prosedur Penelitian Suatu Pendekatan Praktek”. Jakarta: Rineka Cipta.

Bambang Riyanto, (2011). "Dasar-dasar Pembelanjaan Perusahaan”. Edisi ke empat, BPFE Yogyakarta.

Fahmi, Irham (2012), “Pengantar Manajemen Keuangan” Cetakan pertama. Bandung: Penerbit Alfabeta.

Hidayat, A., \& Sunarsi, D. (2020). Faktor-Faktor Yang Mempengaruhi Dana Pihak Ketiga Dan Dampaknya Terhadap Profitabilitas (Survey Pada Bpr Syariah Di Jawa Barat Tahun 20142017). Jurnal Proaksi, 7(1), 54-65.

Imam Ghozali (2017). “Aplikasi Analisis Multivariate Dengan Program SPSS”. Edisi Kelima. Semarang: Badan Penerbit Undip.

Istijanto (2014) "Riset Sumber Daya Manusia”. Jakarta: PT. Gramedia Pustaka

Jasmani, J. (2019). The Effect of Liquidity and Working Capital Turnover on Profitability at PT. Sumber Cipta Multiniaga, South Jakarta. PINISI Discretion Review, 3(1), 29-38. 
Jasmani, Jasmani, and Denok Sunarsi. "The Influence of Product Mix, Promotion Mix and Brand Image on Consumer Purchasing Decisions of Sari Roti Products in South Tangerang." PINISI Discretion Review 1.1 (2020): 165-174.

Kasmir. (2012) “Pengantar Manajemen Keuangan”, Edisi Pertama, Cetakan kedua, Jakarta: Prenada Media.

Martono dan Agus Harjito, (2011). “Manajemen Keuangan”, Jakarta: Penerbit Ekonisia.

Munawir (2010), “Analisis Laporan Keuangan”, Edisi Ke Empat, Penerbit Liberty, Yogyakarta.

Santoso, Singgih (2015). “Menguasai Statistik Multivariat”. Jakarta: PT Elex Media Komputindo.

Sartono, “Manajemen Keuangan Aplikasi Dan Teori”, Edisi Keempat, BPFE, Yogyakarta, 2008.

Sawir, (2003). “Analisis Kinerja Keuangan dan Perencanaan Keuangan Perusahaan”, Cetakan ketiga, Jakarta: Penerbit PT. Gramedia Pustaka Utama.

Sugiyarso, G. dan F. Winarni, "Manajemen Keuangan (Pemahaman Laporan Keuangan, Pengelolaan Aktiva, Kewajiban dan Modal serta Pengukuran

Sugiyono (2017), “Metode Penelitian Administrasi: dilengkapi dengan Metode $R \& D$ ”. Bandung: Alfabeta.

Sunarsi, D. (2018). Pengembangan Sumber Daya Manusia Strategik \& Karakterisrik Sistem Pendukungnya : Sebuah Tinjauan. Jurnal Ilmiah MEA (Manajemen, Ekonomi, \& Akuntansi), 2(3), 178 - 194.

Sutrisno, S., \& Sunarsi, D. (2019). The Effect of Work Motivation and Discipline on Employee Productivity at PT. Anugerah Agung in Jakarta. Jurnal Ad'ministrare, 6(2), 187-196.

Wijoyo, H., Handoko, A. L., Santamoko, R., \& Sunarsi, D. (2020). Strategy Model for Character Education Through Digital Media for Courses and Training Participants. E-Prosiding Pascasarjana Universitas Negeri Gorontalo, 1-8.

Wijoyo, H. (2020). Analisis Pengendalian Internal Dalam Pemberian Kredit Pada PT Bank Perkreditan Rakyat (BPR) Indomitra Mandiri. TIN: Terapan Informatika Nusantara, 1(4), 157-162.

Wijoyo, H. (2018). Analisis Pengakuan Pendapatan dan Beban Kontrak Konstruksi Pada PT. Wahana Tata Riau. Jurnal Ilmu Komputer dan Bisnis, 9(2), 2034-2043.

Yuangga, K. D., \& Sunarsi, D. (2018). The Influence of Procrastination and Low Time Management on Student Self Efficacy (at MA Soebono Mantofani). PINISI Discretion Review, 2(1), 8592. 